\title{
Biofertilizer in leaf and drip applications: an alternative to increase tomato productivity
}

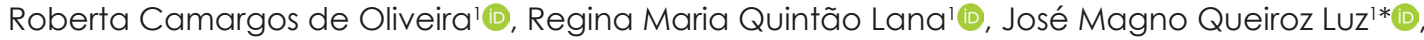 \\ Angelica Araújo Queiroz²D, Danielle Lima Bertoldo'(D)
}

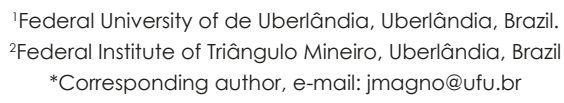

\begin{abstract}
The tomato is a species of undetermined growth and extremely demanding in nutrients Therefore, the search of new ways to maximize the use and supply of fertilizers sources and their application mechanisms are important to improve the tomato culture management. The aim of this study was to evaluate the application methods of liquid biofertilizer (BF) and the harvest times throughout cultivation. The experiment was carried out in a randomized block design, in a $3 \times 6$ factorial with subdivided plot and seven replications. The treatments were foliar and drip BF application and a control, without application of BF, and harvesting time $185 ; 92 ; 99 ; 106 ; 113$; 120 days after transplanting-DAT). Leaf application resulted in a class I production increase in the second week of harvest (92 DAT), while drip application reflected higher class II and III production in the fourth week (106 DAT). In all treatments, at 92 DAT higher production of large fruits (class I) was observed. Production of average fruits (class II) occurred at 92 and 113 DAT and small fruit (class III) production was concentrated at 113 DAT. The adoption of $\mathrm{BF}$, regardless of the application form, provides an increase in total productivity, with an income up to $35 \%$ higher. Therefore, biofertilizer is a good source for nutrition implementation aiming at yields and returns in the tomato production chain.
\end{abstract}

Keywords: Solanum lycopersicum L., fertilizer sources, organomineral, organic matter

\section{Introduction}

Tomato (Solanum lycopersicum L.) is one of the most widely grown vegetables in the world (Maham et al., 2020). The fruits are a great source of nutrients and bioactive compounds, essential to human diet, since has antioxidant and anticancer properties (Briones-Labarca et al., 2019) besides the expressive economic significance (Singh et al., 2020).

Tomato is one of the crops with higher agronomic complexity, which can lead to a high cost and economic risk (Filgueira, 2008; Mitra \& Sharmin, 2019). The average yield of tomato production in Brazil is $62.9 \mathrm{~kg} \mathrm{ha}^{-1}$ (IBGE, 2016). The productivity is influenced by factors, such as adequate management of plant nutrition (Emrich et al., 2011).

The correction of acid soil and suitable fertilizer use potentiate tomato production, which meets market and product demands with low environmental impact.
Organic sources, traditionally underutilized, become interesting options, since they improve the physical, chemical and biological soil properties and make a positive effect on production (Corrêa et al., 2016).

Bissani et al. (2008) point out that organic fertilizers have low concentrations of $\mathrm{N}, \mathrm{P}$ and $\mathrm{K}$, and can be supplemented with mineral fertilization, so that plants can better utilize nutrients through the release timing throughout plant growth.

Some authors (Canellas \& Olivares, 2014; Zandonadi et al., 2014; Prado et al., 2016) mention that biofertilizers (BF) improves the agronomic performance of many crops under conditions of nutritional or climatic stress.

The application of fertilizers through irrigation water (fertigation) is viable way of applying mineral nutrients to the plants. It is possible to maintain more uniform levels of nutrients in the soil, which contribute to 
an increase in fertilization efficiency (Villas Boas et al., 1994).

Although foliar nutrient application is well disseminated researchers suggest the necessity of more studies, since the efficiency of the method can be affected by several factors, especially those related to nutrients source and formulations (Mógor et al., 2013; Carvalho et al., 2014).

$\mathrm{BF}$ is also increasing because is an alternative to minimize ecological imbalances caused by intensive vegetables fertilization with very soluble mineral fertilizers (Rady et al., 2016). It can be a way to take advantage of the wide range of alternative organic matter sources from residues produced in various industrial processes (Canfora et al., 2015). In addition, allow producers to develop sustainable tomato production (Garofalo et al., 2017).

In view of the above, the aim of this study was to evaluate methods of application of liquid biofertilizer (foliar and drip) and harvesting times, in the productivity and income of the Alambra tomato.

\section{Material and Methods}

The experiment was carried out in Capão BonitoSP. Tomato seedlings, cultivar Alambra, were produced in protected cultivation and transplanted to the field at 26 days after sowing, following the double row system, with cross-fence conduction, spaced $1.0 \mathrm{~m} \times 1.2 \mathrm{~m} \times 0.7 \mathrm{~m}$, which resulted in a population of 13.000 plants $\mathrm{ha}^{-1}$.

The soil of the experimental area is classified as
Dark Red Latosol. The physical and chemical analysis of the 0-20 cm layer were as follows: $\mathrm{pH} \mathrm{H}_{2} \mathrm{O}=5.7 ; \mathrm{P}=1.8$ $\mathrm{mg} \mathrm{dm}{ }^{-3} ; \mathrm{K}=83.2 \mathrm{mg} \mathrm{dm}^{-3} ; \mathrm{Ca}=1.6 \mathrm{cmolc} \mathrm{dm}^{-3} ; \mathrm{Mg}=1.8$ $\mathrm{cmol} \mathrm{dm}{ }^{-3} ; \mathrm{Al}=0.2 \mathrm{cmol} \mathrm{dm}^{-3}$, M.O. $=1.9 \%, \mathrm{~V}=45 \%, \mathrm{~T}=$ $4.6 \%$ (EMBRAPA, 1999).

The chemical fertilization followed the recommendations for the crop at São Paulo (Raij et al., 1996) and considering the soil nutrients. Two t ha-1 of dolomitic limestone were applied before planting. In the base fertilization, $3.5 \mathrm{t} \mathrm{ha}^{-1}$ of 04-14-08 were used. In the cover, $100 \mathrm{~kg} 1000$ plants $^{-1}$ of single super phosphate and in fertigation, $2.5 \mathrm{~kg}$ of potassium chloride ( $\mathrm{KCl}$ ) associated with alternate rates between $1.1 \mathrm{~kg}$ of nitro calcium and $1.6 \mathrm{~kg}$ of monoammonium (MAP), were applied every 2 days from 25 days after the transplant (DAT) to the end of the cycle.

The experimental was a randomized block design with factorial arrangement $(3 \times 6)$ and plots subdivided in the time, with seven replications and 20 plants in a total area of $15.4 \mathrm{~m}^{2}$ at each plot. The plots were constituted by treatments with BF in foliar and drip applications and one control, without application of BF and the subplots by harvesting times $(85,92,99,106,113,120$ days after transplanting-DAT).

In the drip application (fertigation), the BF was composed of $437 \mathrm{~g} \mathrm{ha}^{-1}$ of organic matter, $253 \mathrm{~g} \mathrm{ha}^{-1}$ of organic carbon, $230 \mathrm{~g} \mathrm{ha}^{-1}$ of $\mathrm{N}$ and $23 \mathrm{~g} \mathrm{ha}^{-1}$ of $\mathrm{K}_{2} \mathrm{O}$. In the foliar application, the applications were made at time of transplant and at 7, 14, 21, 28, 35, 42 and 56 days after transplanting-DAT (Table 1).

Table 1. Composition of liquid biofertilizer used in foliar application at days after transplantation (DAT).

\begin{tabular}{|c|c|c|c|c|c|}
\hline DAT & $\mathrm{TOM}^{1}$ & $\mathrm{TOC}^{2}$ & Nitrogen (N) & $\mathrm{K}\left(\mathrm{K}_{2} \mathrm{O}\right)$ & Others \\
\hline & \multicolumn{5}{|c|}{$\mathrm{g} \mathrm{ha}^{-1}$} \\
\hline 0 & 517.5 & 299.0 & 261.2 & 25.87 & S: 78; Mg, B, Cu: 6.5 \\
\hline 7 and 14 & 695.75 & 402.5 & 318.7 & 31.62 & S: 78; Mg, B, Cu: 6.5; Mn: 8.62; Zn: 2.87 \\
\hline 21 & 615.25 & 356.5 & 287.5 & 28.75 & Mn: $8.62 ;$ Zn: 2.87 \\
\hline 28 and 35 & 925.75 & 531.8 & 414.0 & 28.75 & Mn: 5.75; Zn: 2.87; B: 5.75; Ca: 254.5 \\
\hline 42 & 609.5 & 350.75 & 354.5 & 23.0 & S:78; Ca: 221.75; B:9.35; Cu, Mg: 6.5 \\
\hline 56 & 437.0 & 253.0 & 320.0 & 923.0 & Ca: $378 ;$ Mg: 49.6; S: 62 \\
\hline
\end{tabular}

Spraying was performed with a $20 \mathrm{~L}$ costly sprayer with working pressure of $4 \mathrm{Kgf}$, and an application drip irrigation was performed with the aid of a fertilizer injector Venturi type. Phytosanitary control was made with insecticides and fungicides recommended for tomatoes, when required.

Harvesting of tomato fruits started at 85 DAT and lasted for six weeks. The fruits were harvested manually classified and weighed. The classification was made according to the regional commercial standard (CEASA CAMPINAS), defined as class I, II and III. The fruits classified as I had diameter higher than $80 \mathrm{~mm}$; those classified as II had a diameter between 50 and $80 \mathrm{~mm}$ and those classified as III had a diameter smaller than $50 \mathrm{~mm}$.

Subsequently the data were extrapolated in order to obtain productivity per hectare. The economic analysis was based on the total produced (sum of classes) during each week of harvest per plot of treatment, estimating the result for a thousand plants. Thus, the number of boxes of tomatoes produced per thousand plants per week was obtained for each treatment. These results were multiplied by the value of the $22 \mathrm{~kg}$ tomato box 
marketed by the owner of the crop, thus obtaining the gross income. By subtracting the cost of production and the cost of applying the BF, the income was obtained.

The production data obtained in each week and total production were submitted for analysis of variance (testF). The regression test was not used for harvest intervals, since the models did not fit the data set, and when there was some case of significance, they presented a low coefficient of determination. Therefore, the Tukey test was used for all factors evaluated. The SISVAR program at the 0.05 level of significance performed the analyses (Ferreira, 2014).

\section{Results and Discussion}

The interaction between treatments and harvest weeks was significant for classes I, II and III (Table 2). Class I fruits (diameter higher than $80 \mathrm{~mm}$ ) showed differences in yield at 92 and 106 harvest DAT. At 92 DAT the foliar application of BF yielded a higher productivity than the others (3601.11 kg ha-1) being the highest yield throughout the tomato cycle.

At 106 DAT plants that received BF (foliar and drip application) were higher than the control (2504.63 and $2363.45 \mathrm{~kg} \mathrm{ha}^{-1}$, respectively) (Table 2).

Table 2. Weekly productivity $\left(\mathrm{kg} \mathrm{ha}^{-1}\right.$ ) of tomato Alambra, classes I, II and III as a function of foliar and drip application of biofertilizers at harvesting- days after transplantation (DAT).

\begin{tabular}{|c|c|c|c|c|c|c|}
\hline \multicolumn{7}{|c|}{ Class I $\left(\mathrm{kg} \mathrm{ha}^{-1}\right)$} \\
\hline & 85 DAT & 92 DAT & 99 DAT & 106 DAT & 113 DAT & 120 DAT \\
\hline Controle $^{1}$ & $1054.5 \mathrm{aD}^{*}$ & $2608.9 \mathrm{cA}$ & $1901.6 \mathrm{aBC}$ & $1843.6 \mathrm{bBC}$ & $2162.0 \mathrm{aAB}$ & $1534.3 \mathrm{aCD}$ \\
\hline Foliar & $1208.2 \mathrm{aC}$ & $3601.1 \mathrm{aA}$ & $1706.8 \mathrm{aC}$ & $2504.6 \mathrm{aB}$ & $2319.2 \mathrm{aB}$ & $1686.2 \mathrm{aC}$ \\
\hline Drip & $1135.7 \mathrm{aE}$ & $3153.8 \mathrm{bA}$ & $1846.0 \mathrm{aCD}$ & $2363.4 \mathrm{aB}$ & $2072.6 \mathrm{aBC}$ & $1475.4 \mathrm{aDE}$ \\
\hline CV (\%) & 14.78 & & & & & \\
\hline \multicolumn{7}{|c|}{ Class II (kg ha-1) } \\
\hline & 85 DAT & 92 DAT & 99 DAT & 106 DAT & 113 DAT & 120 DAT \\
\hline Control' & $981.8 \mathrm{aB}$ & $2075.4 \mathrm{aA}$ & $1382.1 \mathrm{aB}$ & $1414.1 \mathrm{bB}$ & $2319.2 \mathrm{aA}$ & $1213.3 \mathrm{bB}$ \\
\hline Foliar & $939.7 \mathrm{aC}$ & $2303.7 \mathrm{aA}$ & $1567.7 \mathrm{aB}$ & $1685.6 \mathrm{abB}$ & $2694.2 \mathrm{aA}$ & $1521.3 \mathrm{bB}$ \\
\hline Drip & $1051.3 \mathrm{aC}$ & $2311.1 \mathrm{aA}$ & $1771.8 \mathrm{aB}$ & $2029.5 \mathrm{aAB}$ & $2471.2 \mathrm{aA}$ & 1977.7 $\mathrm{aAB}$ \\
\hline CV (\%) & 17.50 & & & & & \\
\hline \multicolumn{7}{|c|}{ Class III $\left(\mathrm{kg} \mathrm{ha}^{-1}\right)$} \\
\hline & 85 DAT & 92 DAT & 99 DAT & 106 DAT & 113 DAT & 120 DAT \\
\hline Control $^{1}$ & $609.7 \mathrm{aC}$ & $1461.9 \mathrm{aA}$ & 9276. $\mathrm{aBC}$ & $1123.3 \mathrm{bAB}$ & $1488.1 \mathrm{aA}$ & $680.1 \mathrm{aC}$ \\
\hline Foliar & $624.6 \mathrm{aD}$ & $1025.0 \mathrm{bBC}$ & $1020.4 \mathrm{aBC}$ & $1300.3 \mathrm{abAB}$ & $1556.0 \mathrm{aA}$ & $754.0 \mathrm{aCD}$ \\
\hline Drip & 5733. $\mathrm{aD}$ & $14.762 \mathrm{aAB}$ & $1113.1 \mathrm{aBC}$ & $1596.5 \mathrm{Aa}$ & $1699.4 \mathrm{aA}$ & $827.8 \mathrm{aCD}$ \\
\hline $\mathrm{CV}(\%)$ & 18.15 & & & & & \\
\hline
\end{tabular}

These data are important, especially considering that tomato price is determined by their size and quality. Thus, the highest fruit prices (the ones with the absence or few defects) are higher in the market, which can be benefitted by the application of BF, as observed in table 2. According to the experiment, it was observed that foliar and drip application of BF constituted in favorable practice to plants and fruit development consequently noticed by productivity increases.

The elements in foliar application (organic matter, organic carbon, macro and micronutrients), each with their functions in the plant metabolism as well as in the factors favoring nutrient aggregation and protection, proved to be interesting alternatives to tomato management. The research, in this sense, corroborates with Ogbomo (2011), who emphasized optimal growth and yield favored by nutrient supplementation through BF application.

In this way, the organic components present in BF formulation generally have the function of optimizing the nutrients absorption contained in them, making the foliar fertilization more efficient.

Studies have shown that phosphorus concentration improvement tended to be higher in tomatoes fertilized with an association between organic and chemical fertilizers, due to the synergism between the sources (Tonfack et al., 2009; Mukhomorov et al., 2016). The synergism between the nutrients and the soil and plant dynamics were observed in this work through the response in the production of foliar and drip applications.

Similar results were observed for class II, where distinct productivity was observed at the fourth and sixth week. In them, drip application showed better results than the other treatments (2029.59 and $1977.73 \mathrm{~kg} \mathrm{ha}^{-1}$, respectively). In all treatments the highest yields were in the second and fifth week (Table 2).

Regarding class III, the highest productivity occurred in the fourth week in drip application. In general, higher and lower productivity were observed in the fifth and first week, respectively (Table 2). 
The BF application (foliar and drip) reflected an increased total productivity compared to the control (only mineral fertilizers). When analyzing total production by classification, it was observed that drip provided a class III increase, which has lower commercial value (Table 3).

Table 3. Productivity per class and total $\left(\mathrm{kg} \mathrm{ha}^{-1}\right)$ of tomato Alambra and comparative economic analysis, estimated per thousand plants, according to biofertilizer application.

\begin{tabular}{|c|c|c|c|c|}
\hline \multicolumn{5}{|c|}{ Total Productivity $\left(\mathrm{kg} \mathrm{ha}^{-1}\right)$} \\
\hline & Control' & Foliar & & \\
\hline Classe I & $11105.28 \mathrm{~b}$ & $13026.57 \mathrm{a}$ & & $a b$ \\
\hline Classe II & $9386.42 \mathrm{~b}$ & $10712.28 a$ & & \\
\hline Classe III & $6291.14 \mathrm{~b}$ & $6280.57 \mathrm{~b}$ & & \\
\hline Total $(|+||+|||)$ & $26782.57 \mathrm{~b}$ & $30019.57 a$ & & \\
\hline $\mathrm{CV}(\%)$ & 7,88 & & & \\
\hline Application & $\begin{array}{c}\text { Gross Income/ } \\
1000 \text { plants }\end{array}$ & $\begin{array}{c}\text { Cost } \\
1000 \text { plants }\end{array}$ & $\begin{array}{l}\text { Cost with } \\
\text { fertilizers } \\
1000 \text { plants }\end{array}$ & $\begin{array}{l}\text { Liquid } \\
\text { Income }\end{array}$ \\
\hline Control' $^{1}$ & $\$ 2018.4$ & $\$ 1162.8$ & - - & $\$ 855.6$ \\
\hline Foliar & $\$ 2269.5$ & $\$ 1162.8$ & $\$ 48.4$ & $\$ 1058.4$ \\
\hline Drip & $\$ 2344.5$ & $\$ 1162.8$ & $\$ 19.1$ & $\$ 1162.6$ \\
\hline
\end{tabular}

Luz et al. (2010) in a study of the effect of BF on tomatoes Debora Pto also found higher productivity in treatments containing BF. The same researchers, as well as Ogbomo (2011), found that BF application, although more expensive, is viable and profitable.

With the sum of productivity in all harvests, it was observed that, regardless of the application form, the BF provided an increase in productivity with income of 23.69 and $35.88 \%$ in foliar and drip application, respectively (Table 3).

It is important to note that the operational cost of fertigation requires a higher initial investment. In addition, some components and nutrients may represent a potential risk of drip obstruction, especially Ca and Mg (Reyes et al., 2008). It is therefore imperative that producers undertake a cost / benefit analysis and evaluate the components that will be used to take the benefits of each technology and management.

Mineral fertilization determines a certain annual variability of yields compared to $\mathrm{BF}$, since organic support provides a steady increase in the evolution of fruit production. The improvement of tomato quality and the preponderance of superior quality classes reflects on the soil-plant system optimization (Heitz et al., 2011). The organic component, as it can be observed in the present work, guaranteed yield and productivity, which corroborates with fruit quality as higher contents of beta-carotene (Lahoz et al., 2016) superoxide dismutase activity and the significant increase in the ascorbic acid contents of mature (Oliveira et al., 2013; Kataok et al., 2017) due to fertilizers organic components.

In a study with cabbage varieties, better yield results were obtained from $\mathrm{BF}$ at the gradual supply of $\mathrm{N}$ required by the crop during the whole cycle, first obtained through the rapid mineralization of $\mathrm{N}$ from inorganic fertilizers and later by the constant release of $\mathrm{N}$ by the fertilizer organic fraction (Carvalho et al., 2014; Olaniyi \& Ojetayo, 2011). This attribute is interesting because it emphasizes that the organic components help maintain high fertility for long periods, which is beneficial for crops with indeterminate growth, such as tomato, that need a high nutrient intake because it has a long period of fruit formation and harvest.

Picolli et al. (2009) also observed positive results of BF application in a study with wheat. Olowokere (2014) recommends $\mathrm{BF}$ for better pepper production, nutrient composition and soil quality.

The favorable response of $\mathrm{BF}$ is related to higher nutritional availability and general conditioning, in relation to soil, water and plant, stimulating plant growth and development (Zandonadi et al., 2014; Prado et al., 2016). Moreover, organic use was considered an efficient way of regulating soil microbial community by promoting beneficial bacteria and suppressing pathogens (Li et al., 2017).

It is observed in the literature contrasting and variable results according to the culture, cultivar, region of cultivation and mainly, regarding the elements involved in the BF used. This reality occurs due to the reactions between the molecules and different metabolic activity, which interacts with the environment and the forms of cultivation, generating effects of synergism or competition among the factors involved.

The BF was considered promising by reducing by $50 \%$ the recommended rates of NPK fertilizers to beans, with low nutrition pollutants and health (Rady et al., 
2016). These same authors believe that BF is an urgent requirement to minimize the environmental pollution that has increased because of inadequate agricultural practices.

The answers obtained by the researchers add to the experiences of the producers. Based on the inferences of each analysis, it is possible to construct perspectives and actions towards a more economically, socially and environmentally viable agriculture. BF can be significant as an effective improvement in the physical, chemical and biological soil attributes and quality crop production attributes, as observed in the present study, as well as a way of using residues produced by the agricultural activity, giving better use and purpose for residues.

\section{Conclusions}

The adoption of $\mathrm{BF}$, regardless of the application form, provides an increase in total productivity, with an income up to $35 \%$ higher. Therefore, BF is a good source for nutrition implementation aiming at yields and returns in the tomato production chain.

\section{Acknowledgments}

The authors wish to thank the Conselho Nacional de Desenvolvimento Científico e Tecnológico (CNPq), Coordenação de Aperfeiçoamento de Pessoal de Nível Superior (CAPES) and Fundação de Amparo à Pesquisa do Estado de Minas Gerais (FAPEMIG) for the financial support.

\section{References}

Bissani, C.A., Gianello, C., Camargo, F.A.O., Tedesco M.J. 2008. Fertilidade dos solos e manejo da adubação das culturas. Gênesis, Porto Alegre, Brazil: 344p.

Briones-Labarca, V., Giovagnoli-Vicuña, C., CañasSarazúa, R. 2019. Optimization of extraction yield, flavonoids and lycopene from tomato pulp by high hydrostatic pressure-assisted extraction. Food Chemistry 278: 751-759.

Canellas, L.P., Olivares, F. 2014. Physiological responses to humic substances as plant growth promoter. Chemical and Biological Technologies in Agriculture 1: 1-11.

Canfora, L., Malusà, E., Salvati, L., Renzi, G., Petrarulo, M., Benedetti, A. 2015. Short-term impact of two liquid organic fertilizers on Solanum lycopersicum L. rhizosphere Eubacteria and Archaea diversity. Applied Soil Ecology 8: 50-59.

Carvalho, R.P., Moreira, R.A., Cruz, M.C.M., Fernandes, D.R., Oliveira, A.F. 2014. Biofertilizer fertilization on the chemical characteristics of Quartzarenic Neosol cultivated with olive tree. Sciencia Horticulturae 176: 120126.

Corrêa, J.C., Grohskopf, M.A., Nicoloso, R.S., Lourenço,
K.S., Martini, R. 2016. Organic, biofertilizer, and mineral fertilizers with urease and nitrification inhibitors for wheat and corn under no-tillage. Pesquisa Agropecuária Brasileira 51: 916-924.

EMBRAPA. 1999. Manual de análise química dos solos, plantas e fertilizantes. Embrapa Solos, Rio de Janeiro, Brazil. $370 \mathrm{p}$.

Emrich, E., Souza, R.J., Lima, A.A., Figueiredo, F.C., Silva, D.R.G. 2011 . Cultivo do tomateiro em substratos orgânicos sob aplicação foliar de silicato de potássio em ambiente protegido. Ciência e Agrotecnologia 35: 56-61.

Ferreira, D.F. 2014. Sisvar: a Guide for its Bootstrap procedures in multiple comparisons. Ciência e Agrotecnologia 38: 109-112.

Filgueira F.A.R. 2008. Novo Manual de Olericultura - Agrotecnologia moderna na produção e comercialização de hortaliças. $3^{a}$ edição. UFV, Viçosa, Brazil. $421 \mathrm{p}$.

Garofalo, P., D'andrea, L., Tomaiuolo, M., Venezia, A., Castrignan, A. 2017. Environmental sustainability of agri-food supply chains in Italy: The case of the wholepeeled tomato production under life cycle assessment methodology. Journal of Food Engineering 200: 1-12.

Heitz, M., Căpuşan, J., Heitz, A.K., Chiper, L., Radu, A., Pojar-Fenesan, M. 2011 . Fertilization systems in the tomato crop in the field. Bulletin UASVM Horticulture 68: 235-237.

IBGE- Instituto Brasileiro de Geografia e Estatística. 2016. Levantamento sistemático da produção agrícola. Rio de Janeiro, 29(6): 1-79. ftp://ftp.ibge.gov.br/Producao_ Agricola/Levantamento_Sistematico_da_Producao_ Agricola_[mensal]/Fasciculo/lspa_201606.pdf <Acessed in: 25 mar. 2020>.

Kataok, K., Sugimoto, K., Ohashi, H., Yamada, H. 2017. Effect of organo-mineral fertilizer on tomato fruit production and incidence of blossom-end rot under salinity. Horticulturae Journal 86: 357-364.

Lahoz, I., Leiva-Brondo, M., Martí, R., Macua, J.I., Campillo, C., Rosellóc S., Cebolla-Cornejo, J. 2016. Influence of high lycopene varieties and organic farming on the production and quality of processing tomato. Sciencia Horticulturae 204: 128-137.

Li, R., Tao, R., Ling, N., Chu, G. 2017. Chemical, organic and bio-fertilizer management practices effect on soil physicochemical property and antagonistic bacteria abundance of a cotton field: Implications for soil biological quality. Soil and Tillage Research 167: 30-38.

Luz, J.M.Q., Bittar, C.A., Queiroz, A.A., Carreon, R. 2010. Produtividade de tomate 'Débora Pto' sob adubação biofertilizer via foliar e gotejamento. Horticultura Brasileira 28: 409-414.

Maham, S.G., Rahimi, A., Subramanian, S., Smith, D.L. 2020. The environmental impacts of organic greenhouse tomato production based on the nitrogen-fixing plant (Azolla). Journal of Cleaner Production 245: 118679. 
Mitra, S., Sharmin, S. 2019. Risk attitudes and financial profitability of tomato farmers - a study in bangladesh. Journal of Agricultural Sciences 14: 207-217.

Mógor, A.F., Barbizan, T., Pauletti, V., Oliveira, J., Bettoni, M.M. 2013. Teores de clorofila em cultivares de tomateiro submetidas a aplicações foliares de magnésio. Pesquisa Agropecuária Tropical 43: 363-369.

Mukhomorov, V.K., Anikina, L., Zvereva, T. 2016. Primary soil formation and dynamics of the evolutional transformation of minerals under action of living matter. Journal of Advances in Natural Sciences 3: 264-276.

Ogbomo, K.E.L. 2011. Comparison of growth, yield performance and profitability of tomato (Solanum lycopersicon) under different fertilizer types in humid forest ultisols. International Journal of Agricultural and Soil Science 1: 332-338.

Olaniyi, J.O., Ojetayo, A.E. 2011 . Effect of fertilizer types on the growth and yield of two cabbage varieties. Journal of Animal and Plant Sciences 12: 1573-1582.

Oliveira, A.B., Moura, C.F.H., Gomes-Filho, E., Marco, C.A., Urban, L., Miranda, M.R.A. 2013. The impact of organic farming on quality of tomatoes is associated to increased oxidative stress during fruit development. Plos One 8: 56354.

Olowokere F.A. 2014. Effect of inorganic and organomineral fertilizers on soil properties and nutrient composition of pepper (Capsicum spp.) Journal of Agricultural Science and Environment 14: 82-96.

Picolli, E.S., Marchioro, V.S., Bellaver, A. 2009. Aplicação de produtos a base de aminoácido na cultura do trigo. Cultivando o Saber 2: 141-148.

Prado, M.R.V., Weber, O.L.S., Moraes, M.F., Santos, C.L.R., Tunes, M.S. 2016. Liquid biofertilizer fertilizer containing humic substances on soybean grown under water stress. Revista Brasileira de Engenharia Agrícola e Ambiental 20: 408-414.

Rady, M.M., Semida, W.M., Hemida, K.A., Abdelhamid, M.T. 2016. The effect of compost on growth and yield of Phaseolus vulgaris plants grown under saline soil. International Journal of Recycling of Organic Waste in Agriculture 5: 311-321.

Raij, B.V., Cantarela, H., Quaggio, J.A., Furlani, A.M.C. 1996. Recomendações de adubação e calagem para - Estado de São Paulo. 2. ed. Instituto Agronômico, Campinas, Brazil. 285 p.

Reyes, L.M., Sanders, D.C., Buhler, W.G. 2008. Evaluation of slow-release fertilizers on bell pepper. Horticulture Technology 18: 393-396.

Singh, H., Kumar, P., Kumar, A., Kyriacou, M.C., Colla, G., Rouphael, Y. 2020. Grafting tomato as a tool to improve salt tolerance. Agronomy 10: 1-22.

Tonfack, L.B., Bernadac, A., Youmbi, E., Mbouapouognigni, V.P., Ngueguim, M., Akoa, A. 2009. Impact of organic and inorganic fertilizers on tomato vigor, yield and fruit composition under tropical andosol soil conditions. Fruits Sciences 64: 167-177.

Villas Boas, R.L., Boaretto, A.E., Vitti, G.C. 1994. Aspectos da fertirrigação. In: Vitti G.C., Boaretto A.E. (Coord.). Fertilizantes fluidos. Potafós, Piracicaba, Brazil. p. 283-308.

Zandonadi, D.B., Santos, M.P., Medici, L.O., Silva, J. 2014. Ação da matéria orgânica e suas frações sobre a fisiologia de hortaliças. Horticultura Brasileira 32: 14-20.

Conflict of Interest Statement: The authors declare that the research was conducted in the absence of any commercial or financial relationships that could be construed as a potential conflict of interest.

All the contents of this journal, except where otherwise noted, is licensed under a Creative Commons Attribution License attribuition-type BY. 